\title{
Aliskiren prevents cardiovascular complications and pancreatic injury in a mouse model of obesity and type 2 diabetes
}

\author{
Y. F. Dong • L. Liu • K. Kataoka • T. Nakamura • \\ M. Fukuda • Y. Tokutomi • H. Nako • H. Ogawa • \\ S. Kim-Mitsuyama
}

Received: 8 July 2009 / Accepted: 16 September 2009 / Published online: 6 November 2009

(C) Springer-Verlag 2009

\begin{abstract}
Aims/hypothesis The effect of renin inhibition on type 2 diabetes is still unclear. The present study was undertaken to examine the efficacy of aliskiren, a direct renin inhibitor, on cardiovascular injuries, glucose intolerance and pancreatic injury in a mouse model of type 2 diabetes.

Methods Groups of $d b / d b$ mice, with obesity and type 2 diabetes, were treated with aliskiren $(3,6,12$ and $25 \mathrm{mg} \mathrm{kg}^{-1}$ day $^{-1}$ ) or hydralazine $\left(80 \mathrm{mg} \mathrm{kg}^{-1}\right.$ day $\left.^{-1}\right)$ for 6 weeks, and the protective effects were extensively compared among groups.

Results All sub-pressor and hypotensive doses of aliskiren significantly attenuated cardiac fibrosis, macrophage infiltration and coronary remodelling, and improved vascular endothelial function in $d b / d b$ mice. These protective effects of aliskiren were attributed to the attenuation of cardiac $\mathrm{p} 22^{\text {phox }}$-related NADPH oxidase-induced superoxide and the restoration of vascular endothelial nitric oxide synthase (eNOS) production. Aliskiren at the highest dose $\left(25 \mathrm{mg} \mathrm{kg}^{-1}\right.$ day $\left.^{-1}\right)$, but not at
\end{abstract}

Electronic supplementary material The online version of this article (doi:10.1007/s00125-009-1575-5) contains supplementary material, which is available to authorised users.

Y. F. Dong $\cdot$ L. Liu $\cdot$ K. Kataoka $\cdot$ T. Nakamura $\cdot$ M. Fukuda

Y. Tokutomi $\cdot$ H. Nako $\cdot$ S. Kim-Mitsuyama $(\triangle)$

Department of Pharmacology and Molecular Therapeutics,

Kumamoto University Graduate School of Medical Sciences,

1-1-1 Honjyo,

Kumamoto 860-8556, Japan

e-mail: kimmitsu@gpo.kumamoto-u.ac.jp

H. Ogawa

Department of Cardiovascular Medicine,

Kumamoto University Graduate School of Medical Sciences,

Kumamoto, Japan lower doses, partially reduced glucose intolerance in $d b / d b$ mice. Furthermore, the highest dose of aliskiren significantly attenuated the decreases in pancreatic islet insulin content and beta cell mass, and prevented pancreatic islet fibrosis in $d b / d b$ mice, being associated with the reduction of 8-hydroxy-2'deoxyguanosine-positive cells and Nox2 (also known as $C y b b)$ expression in pancreatic islets by aliskiren.

Conclusions/interpretation Our work provides the first evidence that direct renin inhibition with aliskiren protects against cardiovascular complications and pancreatic injury, through the attenuation of oxidative stress. Thus, we propose that aliskiren may be a promising therapeutic agent for type 2 diabetes.

Keywords Aliskiren Cardiovascular complications . Insulin resistance $\cdot$ Oxidative stress

$\begin{array}{ll}\text { Abbreviations } \\ \text { ARB } & \text { Angiotensin receptor blocker } \\ \text { DHE } & \text { Dihydroethidium } \\ \text { eNOS } & \text { Endothelial nitric oxide synthase } \\ \text { HOMA-IR } & \text { HOMA of insulin resistance } \\ \text { IGTT } & \text { Intraperitoneal glucose tolerance test } \\ \text { IITT } & \text { Intraperitoneal insulin tolerance test } \\ \text { NOX2 } & \text { NADPH oxidase } 2 \\ \text { 8-OHdG } & \text { 8-Hydroxy-2'-deoxyguanosine } \\ \text { RAS } & \text { Renin-angiotensin system } \\ \text { SNAP } & S \text {-Nitroso- } N \text {-acetylpenicillamine }\end{array}$

\section{Introduction}

Diabetes is a major risk factor for cardiovascular mortality and morbidity [1-5]. Emerging evidence indicates that 
ACE inhibitors and angiotensin receptor blockers (ARBs) slow the progression of type 2 diabetic nephropathy [1-5] and reduce the incidence of new-onset type 2 diabetes [6-9]. Thus, the renin-angiotensin system (RAS) is known to play a key role in the pathogenesis of type 2 diabetes and its complications, and ACE inhibitors and ARBs are now considered as first-line agents for treatment of hypertensive patients with type 2 diabetes. However, it remains to be defined whether this therapeutic strategy with conventional RAS blockers leads to optimum inhibition of tissue RAS.

Aliskiren is the first in a new class of orally effective direct renin inhibitors, and blocks the RAS in different pharmacological mechanisms from those of conventional RAS blockers [10, 11]. Aliskiren not only lowers BP in hypertensive animals and patients $[12,13]$ but also has been recently reported to attenuate cardiovascular and renal injuries in various animal disease models [14-20]. However, there is no report investigating the significance of direct renin inhibition with aliskiren in treatment of type 2 diabetes and its complications.

In this study, using $d b / d b$ mice, a useful model of human type 2 diabetes, we examined the efficacy of aliskiren on cardiovascular injuries, glucose intolerance and pancreatic injury in type 2 diabetic mice. We obtained the first evidence that direct renin inhibition lessens cardiovascular complications and pancreatic injury in type 2 diabetes.

\section{Methods}

Animals and drugs All procedures were in accordance with institutional guidelines for animal research. Male $d b / d b$ mice (C57BLKS/J-lepr $\left.{ }^{d b} / l e p r^{d b}\right)$ and male non-diabetic $d b / m$ mice (C57BLKS/J-lepr ${ }^{d b /+}$ ) as control were purchased from Charles River Laboratories Japan (Yokohama, Japan). All mice were housed in an animal facility with a $12 \mathrm{~h}$ light-darkness cycle and were given standard chow and water ad libitum.

Aliskiren was a kind gift from Novartis (Basel, Switzerland). Hydralazine was purchased from Sigma-Aldrich (St Louis, MO, USA).

Treatment protocol The $d b / d b$ mice at 6 weeks of age already displayed significant obesity and hyperglycaemia. Six-week-old $d b / d b$ mice were assigned to six groups, and were given (1) vehicle, (2) aliskiren $\left(3 \mathrm{mg} \mathrm{kg}^{-1}\right.$ day $\left.^{-1}\right)$, (3) aliskiren $\left(6 \mathrm{mg} \mathrm{kg}^{-1}\right.$ day $\left.^{-1}\right)$, (4) aliskiren $\left(12 \mathrm{mg} \mathrm{kg}^{-1}\right.$ day $^{-1}$ ), (5) aliskiren $\left(25 \mathrm{mg} \mathrm{kg}^{-1} \mathrm{day}^{-1}\right)$ or (6) hydralazine $\left(80 \mathrm{mg} \mathrm{kg}^{-1} \mathrm{day}^{-1}\right.$ ). Vehicle (saline) or aliskiren was s.c. infused into mice via ALZET micro-osmotic pumps (Durect, Cupertino, CA, USA). Hydralazine was given to mice in drinking water. The drug treatments were carried out for 6 weeks (from 6 to 12 weeks of age). Body weight was periodically measured. BP was measured by tail-cuff plethysmography (BP-98A; Softron, Tokyo, Japan) [21] before, and 2, 4 and 6 weeks after the start of drug treatment. After 5 weeks of drug treatment (at 11 weeks of age), an intraperitoneal glucose tolerance test (IGTT) and an intraperitoneal insulin tolerance test (IITT) were performed to evaluate the effect of each treatment on glucose tolerance and insulin sensitivity, respectively. After 6 weeks of drug treatment, 12-week-old mice were anaesthetised with ether, and the heart, aorta and pancreas were rapidly excised to perform biochemical and histological examinations, as described below in detail.

IGTT and IITT For IGTT, mice were deprived of food for $6 \mathrm{~h}$ and then given glucose $(1 \mathrm{mg} / \mathrm{g}$; Wako, Osaka, Japan $)$ by i.p. injection. Caudal vein bloods were taken from mice before, and 30, 60, $120 \mathrm{~min}$ after the injection. Blood glucose concentrations were measured by a portable glucose meter (Sanwa Kagaku Kenkyusho, Nagoya, Japan).

For IITT, 6 h-food-deprived mice were i.p. injected with insulin (2 U/kg; Eli Lilly Japan, Kobe, Japan), and caudal vein bloods were collected before, and 20, 40 and $60 \mathrm{~min}$ after injection, to measure blood glucose concentrations.

HOMA of insulin resistance (HOMA-IR) HOMA-IR, a simple assessment of insulin sensitivity, was calculated by using the following formula: [fasting plasma glucose $(\mathrm{mmol} / \mathrm{l}) \times$ insulin $(\mathrm{pmol} / \mathrm{l})] / 405$. Plasma insulin levels were quantified by using a commercial ELISA kit (Morinaga, Tokyo, Japan).

Vessel ring preparation and organ chamber experiments Isometric tension studies were performed as previously described [22]. In brief, thoracic aortas from mice were cut into $5 \mathrm{~mm}$ rings with special care to preserve the endothelium, and mounted in organ baths filled with modified Tyrode buffer $(\mathrm{pH} 7.4 ; \mathrm{NaCl} 121 \mathrm{mmol} / \mathrm{l}, \mathrm{KCl}$ $5.9 \mathrm{mmol} / \mathrm{l}, \mathrm{CaCl}_{2} 2.5 \mathrm{mmol} / \mathrm{l}, \mathrm{MgCl}_{2} 1.2 \mathrm{mmol} / \mathrm{l}$, $\mathrm{NaH}_{2} \mathrm{PO}_{4} 1.2 \mathrm{mmol} / \mathrm{l}, \mathrm{NaHCO}_{3} 15.5 \mathrm{mmol} / \mathrm{l}$, and D-glucose $11.5 \mathrm{mmol} / \mathrm{l}$ ) aerated with $95 \% \mathrm{O}_{2}$ and $5 \% \mathrm{CO}_{2}$ at $37^{\circ} \mathrm{C}$. The preparations were attached to a force transducer, and isometric tension was recorded on a polygraph. A resting tension of $1 \mathrm{~g}$ was maintained throughout the experiment. Vessel rings were precontracted with L-phenylephrine $\left(10^{-7} \mathrm{~mol} / \mathrm{l}\right)$. After the plateau was attained, the rings were exposed to increasing concentrations of acetylcholine $\left(10^{-9}\right.$ to $10^{-4} \mathrm{~mol} / \mathrm{l}$ ) or $S$-nitroso- $N$-acetylpenicillamine (SNAP; $10^{-9}$ to $\left.10^{-4} \mathrm{~mol} / \mathrm{l}\right)$ to obtain cumulative concentrationresponse curves.

Measurement of tissue superoxide and NADPH oxidase activity Hearts and aortas removed from mice were immediately frozen in Tissue-Tek OCT embedding medium 
(Sakura Finetek, Tokyo, Japan). Dihydroethidium (DHE) was used to evaluate tissue superoxide levels in situ, as described in detail previously [23]. DHE fluorescence of cardiac sections was quantified by Image-Pro Plus v6 analysis software (Media Cybernetics, Bethesda, MD, USA). The mean fluorescence was quantified and expressed relative to values obtained from control mice.

For measurement of cardiac NADPH oxidase activity, cardiac tissues were homogenised with an Ultraturrax T8, centrifuged and NADPH oxidase activity of the resulting supernatant fraction measured by lucigenin chemiluminescence in the presence of $10 \mu \mathrm{mol} / \mathrm{l} \mathrm{NADPH}$ and $10 \mu \mathrm{mol} / 1$ lucigenin as electron acceptor, as described previously [23]. Protein concentrations were measured by the method of Bradford.

Histological and immunohistochemical analysis Hearts and pancreases were fixed in 4\% (wt/vol.) paraformaldehyde, embedded in paraffin, sectioned at $5 \mu \mathrm{m}$, and stained with Sirius Red F3BA $(0.5 \% \mathrm{wt} / \mathrm{vol}$. in saturated aqueous picric acid; Aldrich Chemical Company, St Louis, MO, USA) for the measurement of collagen volume fraction. For cardiac sections, coronary arterial thickness, perivascular fibrosis and interstitial fibrosis were quantified as described previously [24]. For pancreatic sections, fibrosis in and around the islets was quantified as described previously [25].

For CD68 immunohistochemistry, frozen cardiac sections were incubated overnight with rat anti-mouse primary antibody $(\times 500$; Serotec, Raleigh, NC, USA) followed by anti-rat secondary antibody (BioSource, Camarillo, CA, USA), as described previously [21]. For p22 $2^{\text {phox }}$ immunohistochemistry, cardiac paraffin sections $(0.01 \mathrm{~mol} / 1$ citric acid $\mathrm{pH}$ 6.0-antigen unmasked) were incubated overnight with rabbit anti-p22 $2^{\text {phox }}$ primary antibody $(\times 300$; Santa Cruz Biotechnology, Santa Cruz, CA, USA). For insulin immunohistochemistry, pancreatic sections (1 mmol/1 EDTA $\mathrm{pH} 8.0$-antigen unmasked) were incubated overnight with rabbit anti-insulin primary antibody $(\times 100$; Santa Cruz Biotechnology). Both were followed by incubation with horseradish peroxidase (HRP)-conjugated anti-rabbit secondary antibody (ready-to-use; Dako North American, Carpinteria, CA, USA) for $30 \mathrm{~min}$. For NADPH oxidase 2 (NOX2) immunohistochemistry, pancreatic paraffin sections $(0.01 \mathrm{~mol} / 1$ citric acid $\mathrm{pH}$ 6.0-antigen unmasked) were incubated overnight with mouse anti-NOX2 primary antibody $(\times 100$; BD Transduction Laboratories, San Jose, CA, USA), followed by incubation with HRP-conjugated anti-mouse secondary antibody (ready-to-use; Dako North American) for 30 min. A Vector MOM kit (Vector Laboratories, Burlingame, CA, USA) was used for 8-hydroxy-2'-deoxyguanosine (8-OHdG) immunohistochemistry. Pancreatic paraffin sections $(0.01 \mathrm{~mol} / \mathrm{l}$ citric acid $\mathrm{pH}$ 2.0-antigen unmasked) were incubated with mouse anti-human $8-\mathrm{OHdG}$ primary antibody
(10 $\mu \mathrm{g} / \mathrm{ml}$; Japan Institute for the Control of Aging, Shizuoka, Japan). The subsequent steps were according to the instructions of the kit. The above reactions were finally visualised with 3,3'-diaminobenzidine (DakoCytomation, Carpinteria, CA, USA) and counterstained with haematoxylin.

For endothelial nitric oxide synthase (eNOS) immunofluorescence, frozen aortic sections were incubated overnight with mouse anti-eNOS primary antibody $(\times 200$; BD Transduction Laboratories) followed by incubation with FITC-conjugated anti-mouse IgG secondary antibody $(\times 200$; Invitrogen, Tokyo, Japan) for $1 \mathrm{~h}$.

Quantitative analysis of cardiac CD68- and p22 ${ }^{\text {phox }}$ positive cells was done by counting the cell numbers in sections. Cells positive for $8-\mathrm{OHdG}$ staining were identified by the presence of a dark brown nuclear stain and were expressed as a percentage of the total number of islet cells. Intensity of fluorescence for eNOS and the intensity of peroxidase staining for insulin and NOX2 were quantified with Image-Pro Plus v6 analysis software.

Beta cell mass was determined on insulin-stained sections and was estimated by the following formula: beta cell mass $(\mathrm{g})=$ [area of islets/the area of the whole pancreatic area] $\times$ pancreas weight, as described previously [26].

Preparation of cardiac and aortic protein extracts and western blot analysis The detailed method was previously described [27]. Briefly, after left ventricular or aortic protein extracts were subjected to SDS-PAGE and electric transfer to polyvinylidene difluoride membrane, the membranes were probed with specific antibodies. Antibodies used were as follows: anti-phospho-eNOS $(\times 2,000$; BD Transduction Laboratories), anti-p22 $2^{\text {phox }}(\times 1,000$; Santa Cruz Biotechnology) and GAPDH $(\times 5,000$; Santa Cruz Biotechnology).

Quantitative real-time PCR Total RNA was extracted from heart, pancreas and kidney, according to the manufacturer's instruction. One microgram of RNA sample was reverse transcribed to first-strand cDNA using a QuantiTect Reverse Transcription Kit (Qiagen, Tokyo, Japan), according to the manufacturer's recommended protocol. A Thermal Cycler Dice Real Time System (Takara Bio, Shiga, Japan) was used for two-step RT-PCR. cDNA was amplified using SYBR Premix Ex TagTM with specific oligonucleotide primers for target sequences of Nox2 (also known as $C y b b$ ), Nox4, $p 22^{\text {phox }}$ (also known as $C y b a$ ), $p 47^{p h o x}$ (also known as Ncf1), $p 67^{\text {phox }}$ (also known as $N c f 2$ ), renin and $\beta$-actin (see Electronic supplementary material [ESM] Table 1). Amplification conditions included $10 \mathrm{~s}$ at $95^{\circ} \mathrm{C}$ and runs for 40 cycles at $95^{\circ} \mathrm{C}$ for $5 \mathrm{~s}$ and $60^{\circ} \mathrm{C}$ for $30 \mathrm{~s}$, and then dissociation for $15 \mathrm{~s}$ at $95^{\circ} \mathrm{C}$ and $30 \mathrm{~s}$ at $60^{\circ} \mathrm{C}$ on the Thermal Cycler Dice Real Time System. Specificity of the SYBR Premix Ex TagTM assays 
Table 1 Body weight and the weights of left ventricle, pancreas, liver and visceral fat in $d b / m$ mice and $d b / d b$ mice treated with hydralazine or aliskiren for 6 weeks

\begin{tabular}{|c|c|c|c|c|c|}
\hline Mice/treatment & Body weight (g) & Left ventricle (mg) & Pancreas (g) & Liver $(\mathrm{g})$ & Visceral fat $(\mathrm{g})$ \\
\hline$d b / m(n=9)$ & $24.71 \pm 0.33^{* *}$ & $82.92 \pm 3.7$ & $0.22 \pm 0.17 *$ & $1.19 \pm 0.02 * *$ & $0.73 \pm 0.04 * *$ \\
\hline \multicolumn{6}{|l|}{$d b / d b$} \\
\hline Vehicle $(n=13)$ & $46.67 \pm 0.65$ & $89.90 \pm 2.50$ & $0.27 \pm 0.15$ & $2.72 \pm 0.11$ & $4.86 \pm 0.16$ \\
\hline Hydralazine $(n=6)$ & $46.80 \pm 0.87$ & $95.97 \pm 2.22$ & $0.29 \pm 0.13$ & $2.60 \pm 0.09$ & $4.78 \pm 0.17$ \\
\hline \multicolumn{6}{|c|}{ Aliskiren $\left(\mathrm{mg} \mathrm{kg}^{-1}\right.$ day $\left.^{-1}\right)$} \\
\hline $3(n=6)$ & $45.56 \pm 0.54$ & $83.90 \pm 1.95$ & $0.29 \pm 0.20$ & $2.81 \pm 0.05$ & $4.54 \pm 0.21$ \\
\hline $6(n=6)$ & $44.52 \pm 0.35$ & $82.30 \pm 1.25$ & $0.28 \pm 0.17$ & $2.67 \pm 0.08$ & $4.41 \pm 0.09$ \\
\hline $12(n=8)$ & $46.84 \pm 0.81$ & $83.55 \pm 1.84$ & $0.24 \pm 0.18$ & $2.64 \pm 0.06$ & $4.60 \pm 0.16$ \\
\hline $25(n=8)$ & $45.82 \pm 0.83$ & $83.73 \pm 1.14$ & $0.24 \pm 0.26$ & $2.60 \pm 0.09$ & $4.64 \pm 0.20$ \\
\hline
\end{tabular}

Values are means \pm SEM

$* p<0.05, * * p<0.01$ vs vehicle

was confirmed by melting point analysis. Each threshold cycles $\left(C_{\mathrm{t}}\right)$ value was normalised to $\beta$-actin $C_{\mathrm{t}}$ value and a control sample. The delta-delta $C_{\mathrm{t}}$ method, according to the instruction of Thermal Cycler Dice Real Time System, was used for relative quantification.

Statistical analysis Statistical analysis was performed using SPSS 11.5.0 (SPSS, Chicago, IL, USA). Data are presented as means \pm SEM. Statistical significance was determined with one-way ANOVA followed by least square differences analysis. Differences were considered statistically significant at a value of $p<0.05$.

\section{Results}

Body weight and organ weights of $d b / m$ and $d b / d b$ mice As shown in Table 1, body weight and the weights of pancreas, liver and visceral fat were significantly greater in 12-weekold $d b / d b$ mice than the same age of $d b / m$ mice, and these variables were not significantly affected by 6 weeks of treatment with hydralazine or aliskiren.

Effect of aliskiren on BP in db/db mice As shown in Fig. 1, aliskiren, at a dose of $3 \mathrm{mg} \mathrm{kg}^{-1}$ day $^{-1}$, did not significantly lower BP of $d b / d b$ mice throughout the treatment. Aliskiren, at doses of 6,12 and $25 \mathrm{mg} \mathrm{kg}^{-1}$ day $^{-1}$, significantly reduced BP of $d b / d b$ mice in a dose-dependent manner throughout the treatment. Hydralazine treatment reduced BP of $d b / d b$ mice to a degree comparable to aliskiren at $25 \mathrm{mg} \mathrm{kg}^{-1}$ day $^{-1}$.

Aliskiren ameliorated cardiac injuries in $d b / d b$ mice Figures 2 and 3 indicate that cardiac interstitial macrophage infiltration, interstitial fibrosis, coronary arterial thickening and peri-coronary arterial fibrosis were significantly greater in $d b / d b$ mice than in $d b / m$ mice. Aliskiren, at all doses examined, significantly ameliorated these cardiac injuries in $d b / d b$ mice. The magnitude of amelioration of cardiac macrophage infiltration (Fig. 2a) and coronary arterial thickening (Fig. 3b) were similar between the lowest dose $\left(3 \mathrm{mg} \mathrm{kg}^{-1}\right.$ day $\left.^{-1}\right)$ and the highest dose $\left(25 \mathrm{mg} \mathrm{kg}^{-1}\right.$ day $\left.^{-1}\right)$ of aliskiren. Cardiac interstitial (Fig. 2b) and perivascular (Fig. 3c) fibrosis were attenuated by aliskiren in a dosedependent manner. On the other hand, hydralazine treatment did not ameliorate these cardiac injuries in $d b / d b$ mice.

Aliskiren attenuated cardiac superoxide, NADPH oxidase activity and the expression of NADPH oxidase subunit $22^{\text {phox }}$ in $d b / d b$ mice As shown in Fig. 4, cardiac superoxide levels

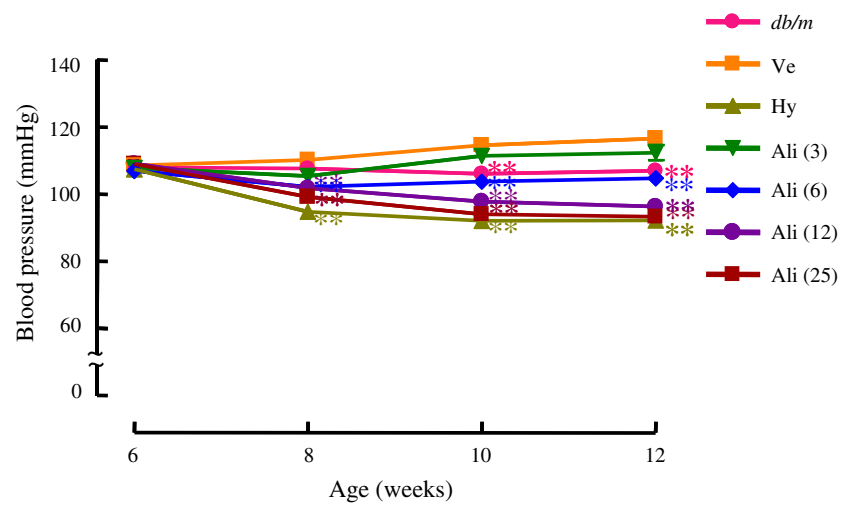

Fig. 1 BP of $d b / m$ mice and $d b / d b$ mice during 6 weeks of treatment with aliskiren and hydralazine. Red circles, $d b / m$ mice; orange squares, vehicle-treated $d b / d b$ mice; gold triangles, hydralazine $\left(80 \mathrm{mg} \mathrm{kg}^{-1} \mathrm{day}^{-1}\right)$-treated $d b / d b$ mice; inverted green triangles, aliskiren ( $3 \mathrm{mg} \mathrm{kg}^{-1} \mathrm{day}^{-1}$ )-treated $d b / d b$ mice; blue diamonds, aliskiren (6 mg kg$\left.{ }^{-1} \mathrm{day}^{-1}\right)$-treated $d b / d b$ mice; purple circles, aliskiren (12 $\left.\mathrm{mg} \mathrm{kg}^{-1} \mathrm{day}^{-1}\right)$-treated $\mathrm{db} / \mathrm{db}$ mice; brown squares, aliskiren $\left(25 \mathrm{mg} \mathrm{kg}^{-1} \mathrm{day}^{-1}\right)$-treated $d b / d b$ mice. ${ }^{* *} p<0.01$ vs vehicle-treated. Values are means $\pm \operatorname{SEM}(n=6-13)$ 
Fig. 2 Cardiac macrophage infiltration (a) and interstitial fibrosis (b) in $d b / m$ mice and $d b / d b$ mice. Ve, vehicle-treated; Hy, hydralazine (80 $\mathrm{mg} \mathrm{kg}^{-1}$ day $^{-1}$ )-treated; Ali (3), Ali (6), Ali (12) and Ali (25), treated with aliskiren at 3 , 6, 12 and $25 \mathrm{mg} \mathrm{kg}^{-1}$ day $^{-1}$, respectively. a Includes representative photomicrographs of cardiac sections immunostained with anti-CD68 antibody. Scale bar, $200 \mu \mathrm{m}$. b Includes a representative Sirius Red-stained cardiac sections. Scale bar, $50 \mu \mathrm{m} . * p<0.05, * * p<0.01$ vs vehicle-treated. Values are means \pm SEM $(n=6-13)$ a
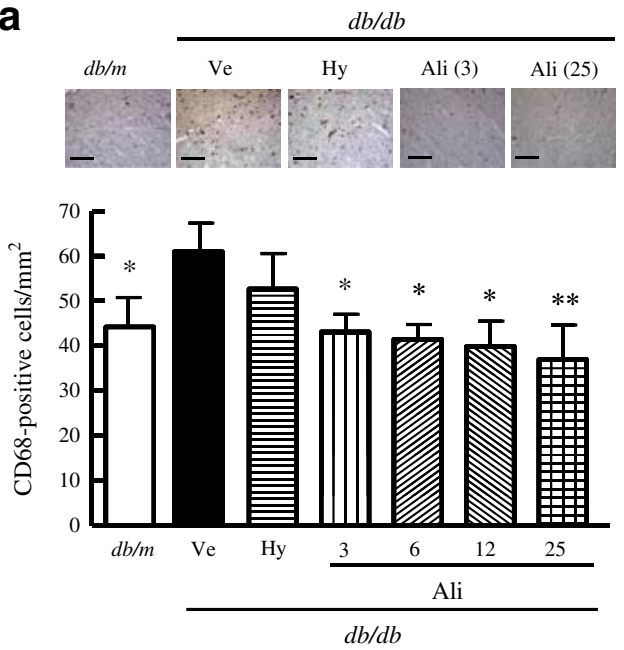

b
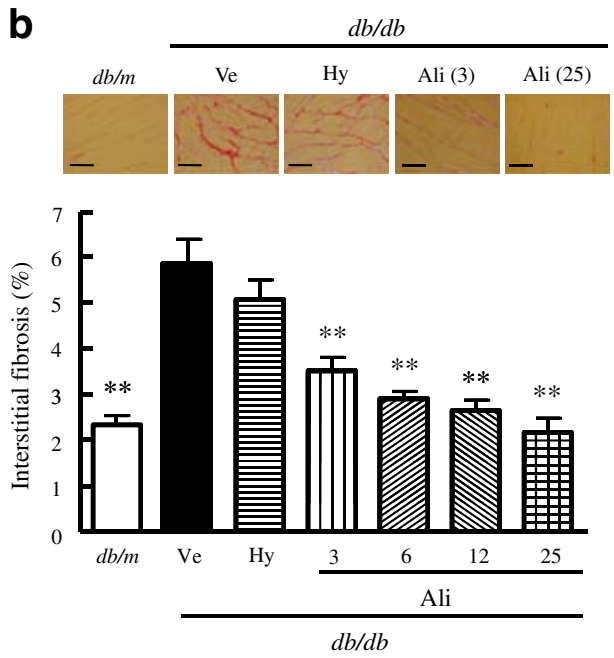

$(p<0.01)$ and NADPH oxidase activity $(p<0.01)$ were significantly higher in $d b / d b$ mice than $d b / m$ mice. All doses of aliskiren significantly reduced cardiac superoxide and NADPH oxidase activity in $d b / d b$ mice.

As shown in Fig. 5, cardiac mRNA expressions of Nox2, Nox4, $p 47^{p h o x}$ and $p 67^{p h o x}$ were not different between $d b / d b$ mice and $d b / m$ mice, and these mRNA expressions of $d b / d b$ mice were not significantly affected by any drug treatment. On the contrary, as shown in Fig. 6a, cardiac mRNA expression of $p 22^{p h o x}$ was significantly greater in $d b / d b$ mice than in $d b / m$ mice $(p<0.05) . p 22^{\text {phox }}$ mRNA expression in $d b / d b$ mice was significantly reduced by aliskiren at all doses. Cardiac $\mathrm{p} 22^{\text {phox }}$ protein levels in $d b / d b$ mice were also higher than in $d b / m$ mice $(p<0.05)$, and were significantly reduced by the lowest $\left(3 \mathrm{mg} \mathrm{kg}^{-1} \mathrm{day}^{-1}\right)$ or the highest $\left(25 \mathrm{mg} \mathrm{kg}^{-1} \mathrm{day}^{-1}\right)$ dose of aliskiren $(p<0.01$;
Fig. 6b). Furthermore, the number of cardiac p22 $2^{\text {phox }}$ protein-positive cells was significantly greater in $d b / d b$ mice than $d b / m$ mice $(p<0.05)$, and aliskiren significantly reduced the number of cardiac p22 $2^{\text {phox }}$-positive cells in $d b / d b$ mice $(p<0.01$; Fig. $6 c)$.

By contrast, hydralazine treatment failed to ameliorate any of these variables in $d b / d b$ mice.

Aliskiren preserved vascular endothelial function in $d b / d b$ mice As shown in Fig. 7a, compared with $d b / m$ mice, vascular endothelium-dependent relaxation by acetylcholine was significantly impaired in $d b / d b$ mice $(p<0.01)$. Aliskiren, at all doses tested, significantly preserved vascular endothelial function in $d b / d b$ mice. However, hydralazine failed to restore vascular endothelial function in $d b / d b$ mice.
Fig. 3 a Representative photomicrographs of Sirius Redstained cardiac sections. Scale bar, $50 \mu \mathrm{m}$. Coronary arterial thickening (b) and peri-coronary arterial fibrosis (c) in hearts of $d b / m$ mice and $d b / d b$ mice. Ve, vehicle-treated; Hy, hydralazine $\left(80 \mathrm{mg} \mathrm{kg}^{-1}\right.$ day $\left.^{-1}\right)$-treated; Ali (3), Ali (6), Ali (12) and Ali (25), treated with aliskiren at 3 , 6,12 and $25 \mathrm{mg} \mathrm{kg}^{-1}$ day $^{-1}$, respectively. ${ }^{*} p<0.05$, $* * p<0.01$ vs vehicle-treated. Values are means \pm SEM $(n=6-13)$

a

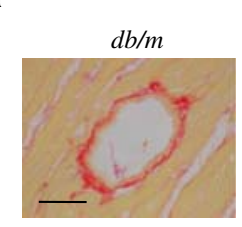

b

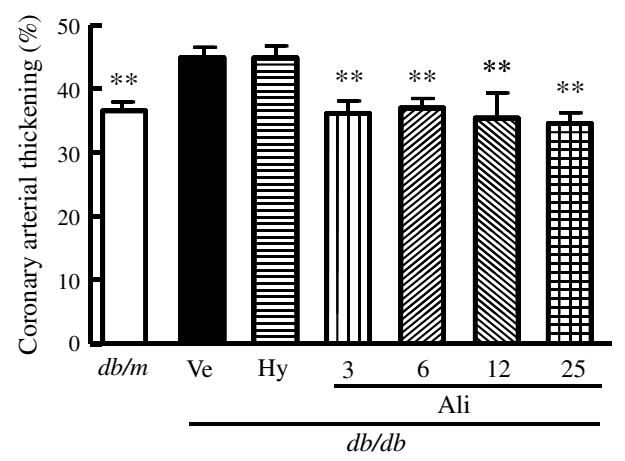

$d b / d b$

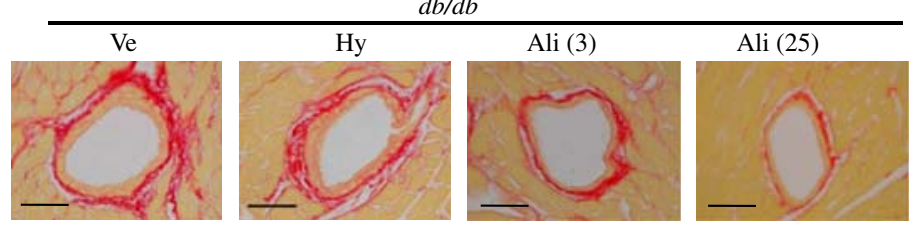

C

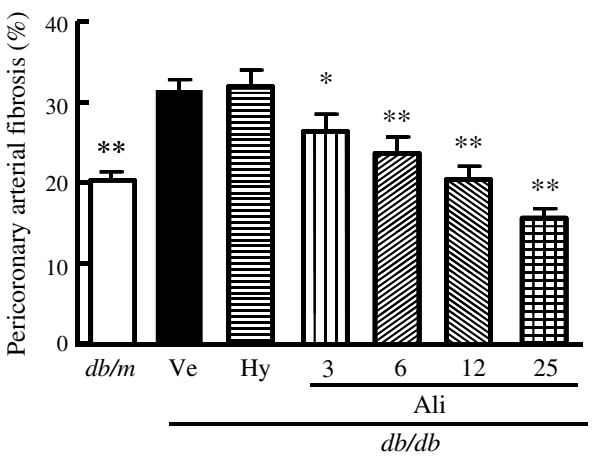


Fig. 4 a Representative photomicrographs of DHE-stained cardiac sections. Scale bar, $100 \mu \mathrm{m}$. Cardiac superoxide levels (b) and NADPH oxidase activity (c) in $d b / m$ mice and $d b / d b$ mice. Ve, vehicletreated; Hy, hydralazine $\left(80 \mathrm{mg} \mathrm{kg}^{-1}\right.$ day $\left.^{-1}\right)$-treated; Ali (3), Ali (6), Ali (12) and Ali (25), treated with aliskiren at $3,6,12$ and $25 \mathrm{mg} \mathrm{kg}^{-1}$ day $^{-1}$, respectively. KCPM, kilocounts/min. ${ }^{*} p<0.05$, $* * p<0.01$ vs vehicle-treated. Values are means \pm SEM $(n=6-13)$ a $d b / d b$

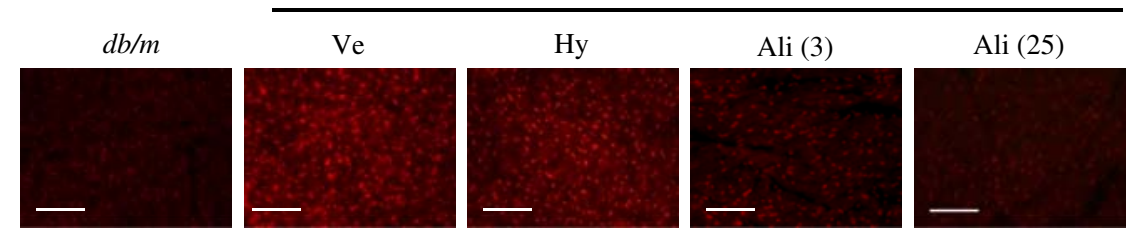

b

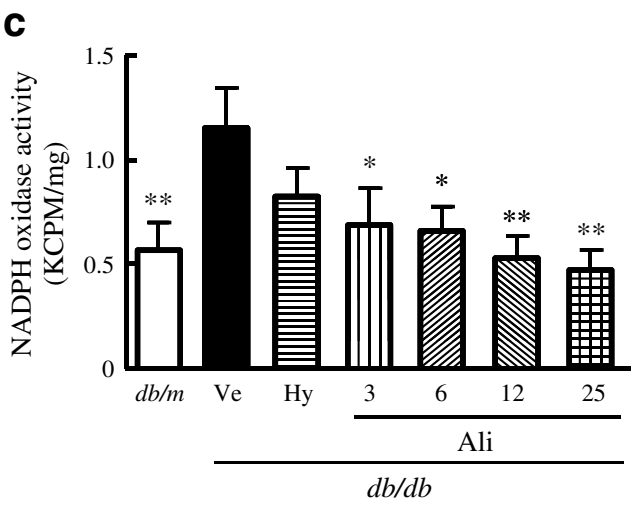

As shown in Fig. 7b, vascular endothelium-independent relaxation by SNAP was not impaired in $d b / d b$ mice and was not affected by any drug treatment.

Aliskiren attenuated aortic superoxide and restored vascular endothelial production of eNOS in $d b / d b$ mice As shown in Fig. 8a, aortic superoxide was significantly greater in $d b / d b$ mice than $d b / m$ mice $(p<0.01)$. Aliskiren, at all doses tested, significantly reduced aortic superoxide in $d b / d b$ mice $(p<0.01)$. Hydralazine treatment did not affect aortic superoxide in $d b / d b$ mice.

As shown in Fig. 8b, vascular endothelial production of eNOS was significantly reduced in $d b / d b$ mice compared with $\mathrm{db} / \mathrm{m}$ mice $(p<0.01)$. Both the highest dose $\left(25 \mathrm{mg} \mathrm{kg}^{-1}\right.$ day $\left.^{-1}\right)$ and the lowest dose $\left(3 \mathrm{mg} \mathrm{kg}^{-1}\right.$ day $\left.^{-1}\right)$ of aliskiren significantly restored vascular eNOS production in $d b / d b$ mice. Hydralazine did not affect eNOS production in $d b / d b$ mice. Western blot analysis of aortic phospho-eNOS (Fig. 8c) showed that phospho-eNOS levels in $d b / d b$ mice were attenuated compared with $d b / m$ mice and were apparently increased by aliskiren treatment but not by hydralazine treatment.

Aliskiren partially improved glucose tolerance, increased pancreatic islet insulin content and beta cell mass, and attenuated islet fibrosis in $\mathrm{db} / \mathrm{db}$ mice Table 2 shows blood
Fig. 5 mRNA expression of Nox2 (a), Nox4 (b), p4 $7^{\text {phox }}$ (c) and $p 67^{\text {phox }}(\mathbf{d})$ in hearts of $d b / m$ mice and $d b / d b$ mice. Ve, vehicle-treated; Hy, hydralazine (80 $\mathrm{mg} \mathrm{kg}^{-1}$ day $^{-1}$ )-treated; Ali (3), Ali (6), Ali (12) and Ali (25), treated with aliskiren at 3 , 6,12 and $25 \mathrm{mg} \mathrm{kg}^{-1}$ day $^{-1}$ respectively. mRNA levels of each subunit in individual sample were corrected for $\beta$-actin mRNA levels. Values are means \pm SEM $(n=6-13)$ a

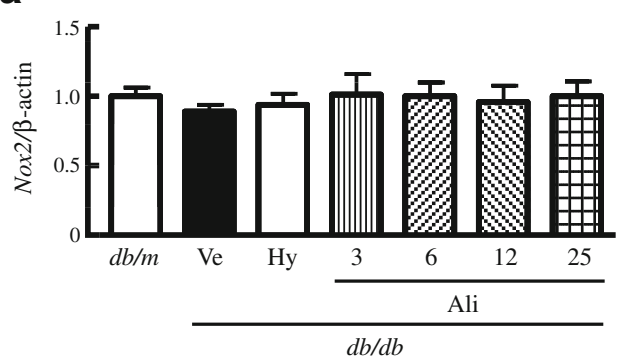

C

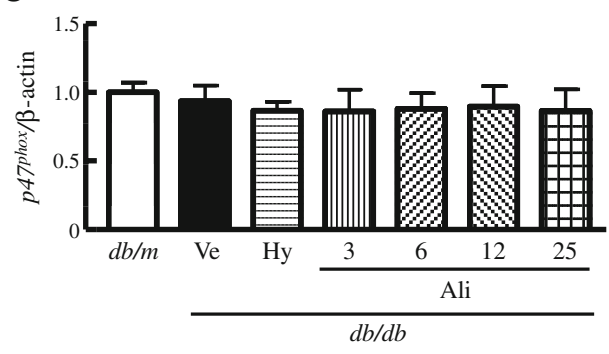

b

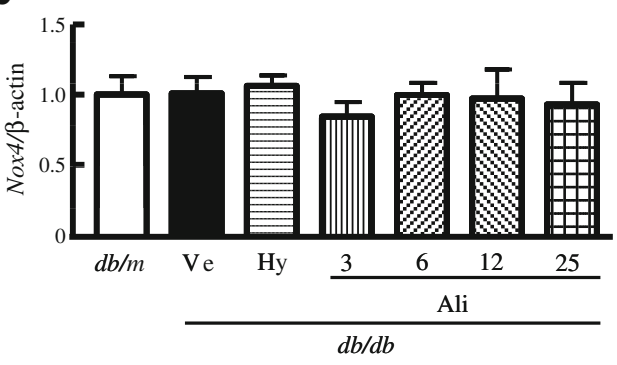

d

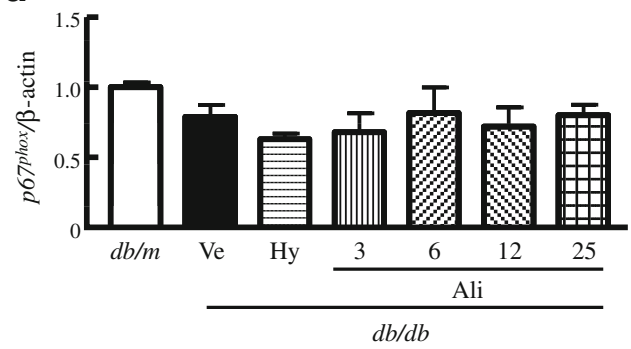


a

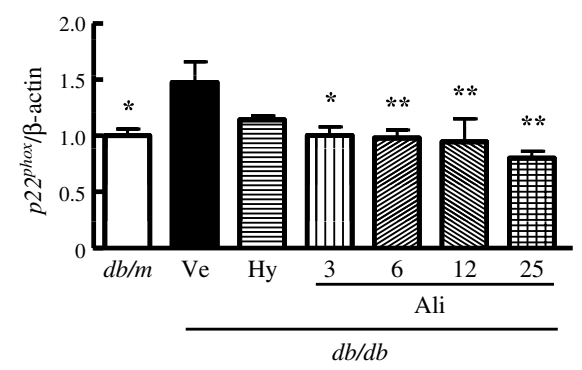

Fig. 6 p $22^{\text {phox }}$ mRNA expression (a), p22 $2^{\text {phox }}$ protein levels (b) and p22 $2^{\text {phox }}$ protein-positive cells (c) in hearts of $d b / m$ mice and $d b / d b$ mice. Ve, vehicle-treated; Hy, hydralazine $\left(80 \mathrm{mg} \mathrm{kg}^{-1} \mathrm{day}^{-1}\right)$-treated; Ali (3), Ali (6), Ali (12) and Ali (25), treated with aliskiren at 3, 6, 12

glucose and plasma insulin levels before and 5 weeks after the start of drug treatment. $d b / d b$ mice at 6 weeks of age (before the start of drug treatment) exhibited hyperglycaemia and hyperinsulinaemia.

IGTTs (Fig. 9a) indicated that aliskiren at the highest dose $\left(25 \mathrm{mg} \mathrm{kg}{ }^{-1}\right.$ day $^{-1}$ ) significantly decreased blood glucose concentrations at $30 \mathrm{~min}$ after glucose injection. There was a trend for aliskiren to reduce AUC in the IGTT, but the difference was not statistically significant (Fig. 9b). All lower doses of aliskiren (3, 6 and $12 \mathrm{mg} \mathrm{kg}^{-1}$ day $^{-1}$ ) failed to improve glucose tolerance in $d b / d b$ mice (data not shown). Hydralazine treatment did not improve glucose tolerance. c
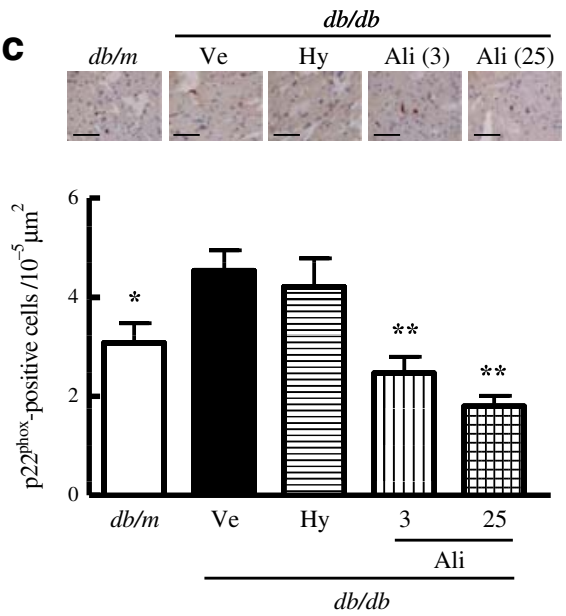

and $25 \mathrm{mg} \mathrm{kg}^{-1} \mathrm{day}^{-1}$, respectively. b, c Include representative western blots of $\mathrm{p} 22^{\text {phox }}(\mathbf{b})$ and photomicrographs of cardiac sections immunostained with anti-p22 $2^{\text {phox }}$ antibody (c). Scale bar, $50 \mu \mathrm{m}$. a-c ${ }^{*} p<0.05,{ }^{*} p<0.01$ vs vehicle-treated. Values are means $\pm \operatorname{SEM}(n=6-13)$

IITTs (Fig. 9c) showed that plasma glucose levels at $20 \mathrm{~min}$ after insulin injection were lower in aliskiren (25 mg kg${ }^{-1}$ day $^{-1}$ )-treated $d b / d b$ mice than vehicle-treated $d b / d b$ mice. The increased HOMA-IR in $d b / d b$ mice was significantly attenuated by aliskiren treatment $(p<0.05)$ but not by hydralazine treatment (Fig. 9d).

As shown in Fig. 10a, b, pancreatic insulin content $(p<0.01)$ and beta cell mass $(p<0.05)$ were less in $d b / d b$ mice than $d b / m$ mice. Aliskiren at $25 \mathrm{mg} \mathrm{kg}^{-1}$ day $^{-1}$ prevented the decrease in islet insulin content $(p<0.05)$ and beta cell mass $(p<0.05)$ in $d b / d b$ mice. As shown in Fig. 10c, islet fibrosis in $d b / d b$ mice was much greater than $d b / m$ mice

Fig. 7 Vascular endotheliumdependent relaxation by acetylcholine (a) and endotheliumindependent relaxation by SNAP (b) in aortas of $d b / m$ mice and $d b / d b$ mice. Red circles, $d b / m$ mice; orange squares, vehicle-treated $d b / d b$ mice; gold triangles, hydralazine $\left(80 \mathrm{mg} \mathrm{kg}^{-1}\right.$ day $\left.^{-1}\right)$-treated $d b / d b$ mice; inverted green triangles, aliskiren $\left(3 \mathrm{mg} \mathrm{kg}^{-1}\right.$ day $^{-1}$ )-treated $d b / d b$ mice; blue diamonds, aliskiren $\left(6 \mathrm{mg} \mathrm{kg}^{-1}\right.$ day $\left.^{-1}\right)$-treated $d b / d b$ mice; purple circles, aliskiren $\left(12 \mathrm{mg} \mathrm{kg}^{-1} \mathrm{day}^{-1}\right.$ )-treated $d b / d b$ mice; brown squares, aliskiren $\left(25 \mathrm{mg} \mathrm{kg}^{-1}\right.$ day $\left.^{-1}\right)$ treated $d b / d b$ mice. a $* p<0.05$, $* * p<0.01$ vs vehicle-treated. Values are means \pm SEM $(n=6-13)$

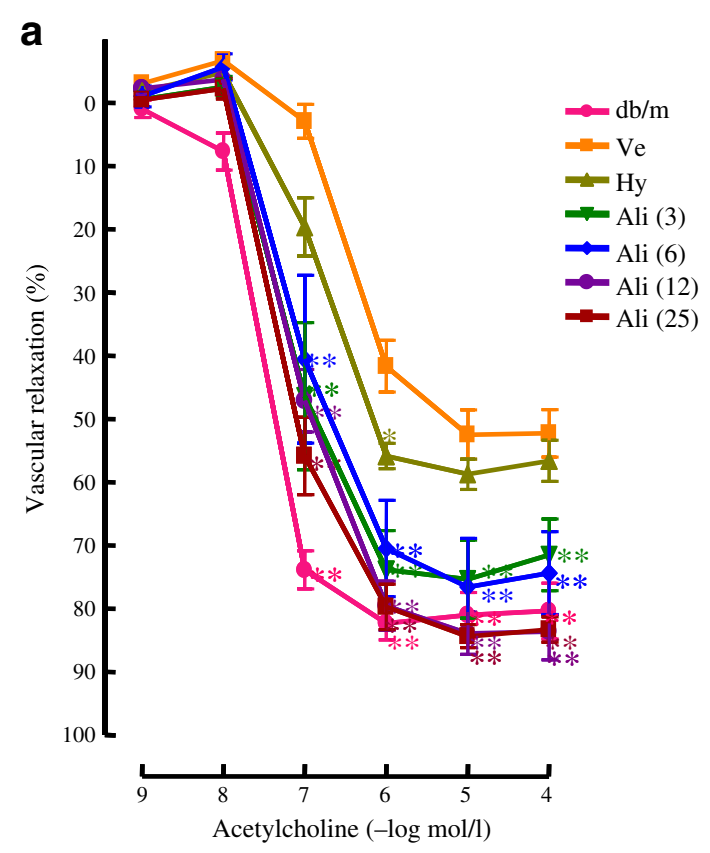

b

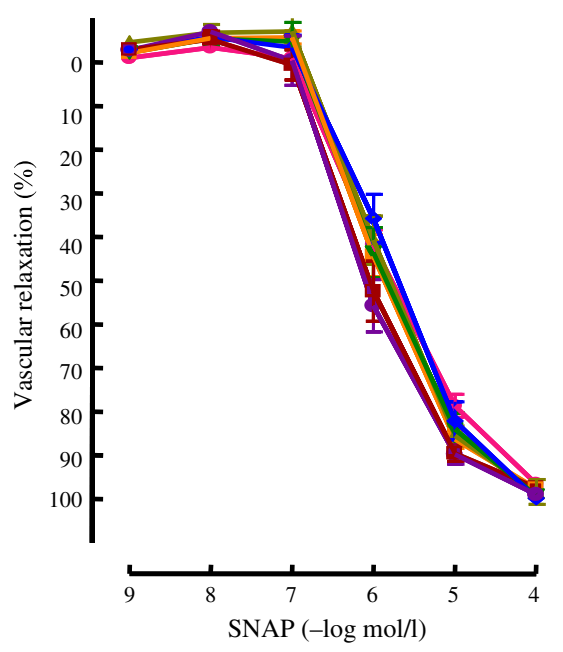


a
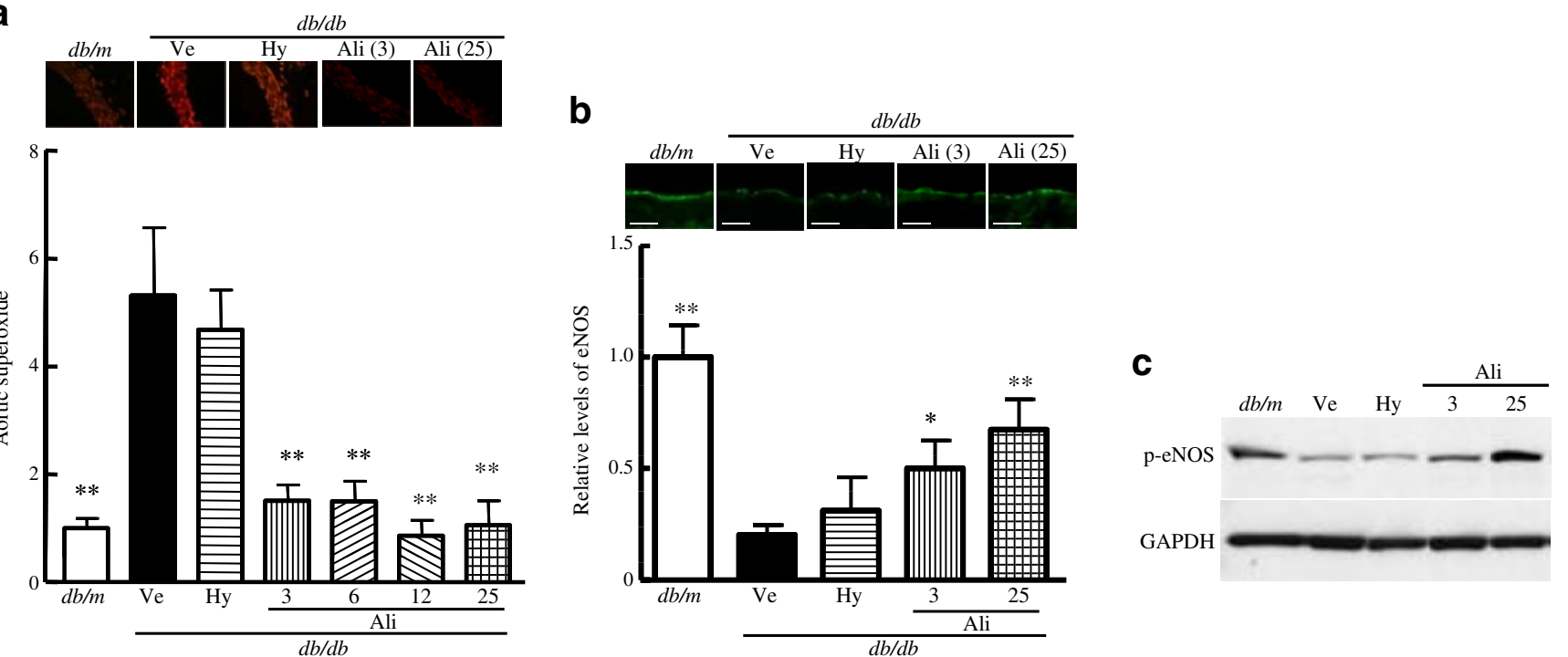

Fig. 8 Superoxide (a), eNOS (b) and phospho-eNOS (c) levels in aortas of $d b / m$ mice and $d b / d b$ mice. Ve, vehicle-treated; Hy, hydralazine (80 $\mathrm{mg} \mathrm{kg}^{-1}$ day $\left.^{-1}\right)$-treated; Ali (3), Ali (6), Ali (12) and Ali (25), treated with aliskiren at $3,6,12$ and $25 \mathrm{mg} \mathrm{kg}^{-1} \mathrm{day}^{-1}$, respectively. a Upper panels are representative photomicrographs of DHE-stained aortic sections. Scale bar, $50 \mu \mathrm{m}$. b Upper panels are aortic

$(p<0.01)$, and was significantly reduced by aliskiren $\left(25 \mathrm{mg} \mathrm{kg}^{-1} \mathrm{day}^{-1}\right)$. However, lower doses of aliskiren (3, 6 and $12 \mathrm{mg} \mathrm{kg}^{-1}$ day $^{-1}$ ) did not significantly improve these pancreatic changes (data not shown). Hydralazine treatment did not improve these pancreatic changes in $d b / d b$ mice.

\section{Aliskiren reduced 8-OHdG-positive cells and expression of}

Nox2 in pancreatic islets in $d b / d b$ mice As shown in Fig. 11a, the ratio of 8-OHdG-positive cells was significantly higher in $d b / d b$ mice than $d b / m$ mice $(p<0.01)$, and in $d b / d b$ mice was significantly reduced by aliskiren (25 mg kg ${ }^{-1}$ day $\left.^{-1} ; p<0.05\right)$. As shown in Fig. $11 \mathrm{~b}$, c, mRNA expression and protein levels of Nox2 were significantly higher in $d b / d b$ mice than in $d b / m$ mice. Aliskiren $\left(25 \mathrm{mg} \mathrm{kg}^{-1} \mathrm{day}^{-1}\right)$ significantly and similarly reduced the increased mRNA expression and protein levels of Nox2 in $d b / d b$ mice, while hydralazine did not reduce sections immunostained with eNOS antibody. Scale bar, $20 \mu \mathrm{m}$. Values are means \pm SEM $(n=6-13)$. c Western blot analysis of phospho-eNOS (p-eNOS) and GAPDH was performed on the pooled aortic tissues from three or four mice. Phospho-eNOS levels in $d b / d b$ mice were decreased compared with $\mathrm{db} / \mathrm{m}$ mice, and were apparently increased by aliskiren but not by hydralazine. ${ }^{*} p<0.05,{ }^{* *} p<0.01$ vs vehicle-treated

them. Lower doses $\left(3,6\right.$ and $12 \mathrm{mg} \mathrm{kg}^{-1}$ day $\left.^{-1}\right)$ of aliskiren failed to improve these variables.

Effect of each treatment on renal renin mRNA expression in $d b / d b$ mice As shown in Fig. 12, treatment of $d b / d b$ mice with aliskiren significantly increased renal renin mRNA expression in a dose-dependent manner.

\section{Discussion}

The major finding of this study was that direct renin inhibition with aliskiren exerts beneficial effects on cardiovascular injury, glucose intolerance and pancreatic injury in obese type 2 diabetic mice, thereby highlighting aliskiren as a promising therapeutic agent for type 2 diabetes and its complications.

Currently, the impact of a renin inhibitor on diabetes and its complications remains to be defined. Recent reports [28, 29]
Table 2 Blood glucose and plasma insulin before and 5 weeks after start of drug treatment

Values are means \pm SEM

a $25 \mathrm{mg} \mathrm{kg}^{-1}$ day $^{-1}$

${ }^{*} p<0.01$ vs vehicle

\begin{tabular}{|c|c|c|c|c|}
\hline \multirow[t]{2}{*}{ Mice/treatment } & \multicolumn{2}{|c|}{ Blood glucose $(\mathrm{mmol} / \mathrm{l})$} & \multicolumn{2}{|c|}{ Plasma insulin (pmol/l) } \\
\hline & Before & After & Before & After \\
\hline$d b / m(n=9)$ & $13.5 \pm 0.6^{*}$ & $11.5 \pm 0.6^{*}$ & $179 \pm 31^{*}$ & $149 \pm 20^{*}$ \\
\hline \multicolumn{5}{|l|}{$d b / d b$} \\
\hline Vehicle $(n=13)$ & $20.8 \pm 0.9$ & $37.0 \pm 2.2$ & $1,632 \pm 214$ & $845 \pm 117$ \\
\hline Hydralazine $(n=6)$ & $18.7 \pm 2.0$ & $35.3 \pm 2.6$ & $1,702 \pm 88$ & $806 \pm 166$ \\
\hline Aliskiren $(n=8)^{\mathrm{a}}$ & $21.2 \pm 1.8$ & $32.2 \pm 2.2$ & $1,720 \pm 170$ & $681 \pm 74$ \\
\hline
\end{tabular}


a

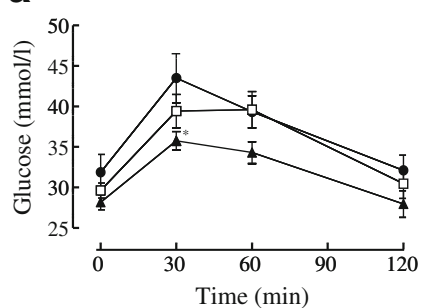

c

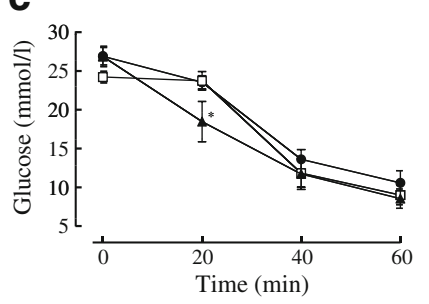

b

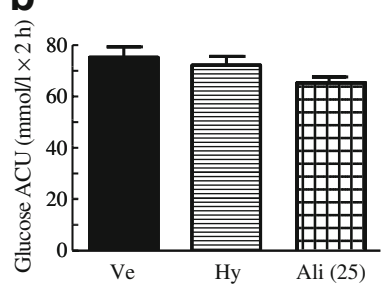

d

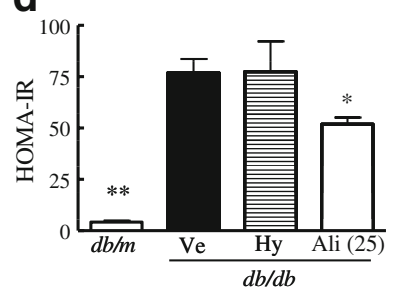

Fig. 9 IGTT (a), IGTT AUC (b), IITT (c) and HOMA-IR (d) in $d b / d b$ mice. Ve, vehicle-treated; Hy, hydralazine $\left(80 \mathrm{mg} \mathrm{kg}^{-1}\right.$ day $\left.^{-1}\right)$-treated; Ali (25), aliskiren (25 mg kg${ }^{-1}$ day $^{-1}$ )-treated. a, c Black circles, vehicle-treated; white squares, hydralazine $\left(80 \mathrm{mg} \mathrm{kg}^{-1} \mathrm{day}^{-1}\right)$ treated; black triangles aliskiren $\left(25 \mathrm{mg} \mathrm{kg}^{-1}\right.$ day $\left.{ }^{-1}\right)$-treated. ${ }^{*} p<0.05,{ }^{*} p<0.01$ vs vehicle-treated. Values are means $\pm \operatorname{SEM}(n=6-13)$

show that a hypotensive dose of aliskiren attenuates insulin resistance, pancreatic oxidative stress and remodelling, and improves skeletal muscle glucose transport in the transgenic $\mathrm{TG}(\mathrm{mRen}-2) 27$ rat, which overexpresses the mouse renin transgene and is hypertensive. However, importantly, the transgenic TG(mRen-2)27 rat does not display hyperglycaemia and is not a diabetic model. A hypotensive dose of aliskiren is also shown to prevent renal injury in streptozotocin-induced type 1 diabetic transgenic TG (mRen-2)27 rats [14, 30]. Furthermore, aliskiren was

recently reported to suppress cardiomyocyte apoptosis and interstitial fibrosis in streptozotocin-induced type 1 diabetic rats, although the role of BP was not examined in that report [31]. However, to the best of our knowledge, all previous studies [14, 30, 31] investigating the effects of aliskiren on diabetes are limited to type 1 diabetic models. Taken together with the fact that the underlying pathogenic mechanisms markedly differ between type 2 and type 1 diabetes, these findings encouraged us to examine for the first time the efficacy of aliskiren on type 2 diabetic $d b / d b$ mice. $d b / d b$ mice $[32,33]$ are characterised by obesity, insulin resistance, severe hyperglycaemia, pancreatic injury and cardiovascular complications, and therefore are regarded as a useful model of human type 2 diabetes.

In this study, aliskiren at various doses ranging from 3 to $25 \mathrm{mg} \mathrm{kg}^{-1}$ day $^{-1}$ was given to $d b / d b$ mice, since previous reports $[16,27]$ indicate that such doses of aliskiren in vivo specifically and significantly inhibits plasma renin in mice. In accord with the previous report [16], aliskiren, at all doses used in this study, significantly increased renal renin mRNA in a dose-dependent manner (Fig. 12), confirming the significant suppression of RAS by aliskiren in vivo. Aliskiren, at all doses tested in this study, markedly prevented cardiovascular injuries in $d b / d b$ mice. Of note are the observations that aliskiren at the lowest dose ( $3 \mathrm{mg} \mathrm{kg}^{-1} \mathrm{day}^{-1}$ ), without apparently lowering BP, markedly prevented cardiac injury, as shown by the attenuation of cardiac macrophage infiltration, cardiac interstitial fibrosis and coronary arterial thickening, and also ameliorated vascular endothelial dysfunction in $d b / d b$ mice. Furthermore, BP lowering with hydralazine treatment did not significantly ameliorate cardiovascular injuries in $d b / d b$ mice. Collectively, our current findings provide the first a
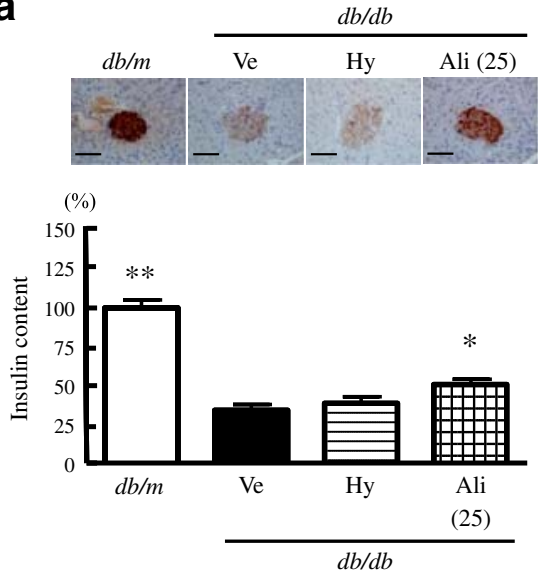

b

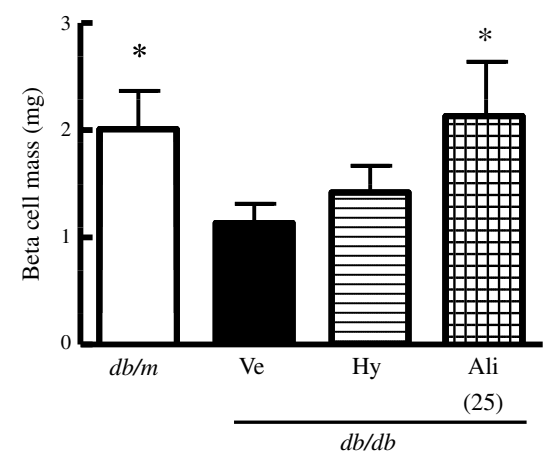

C
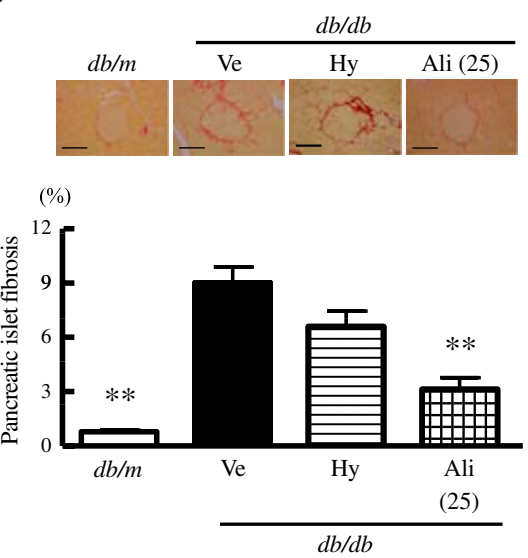

Fig. 10 Insulin content (a), beta cell mass (b) and fibrosis (c) in pancreatic islets of $d b / m$ mice and $d b / d b$ mice. Ve, vehicle-treated; Hy, hydralazine (80 mg kg-1 $\mathrm{day}^{-1}$ )-treated; Ali (25), aliskiren $\left(25 \mathrm{mg} \mathrm{kg}^{-1}\right.$ day $\left.^{-1}\right)$-treated. a Upper panels are representative photo- micrographs of pancreatic sections immunostained with anti-insulin antibody. Scale bar, $100 \mu \mathrm{m}$. c Upper panels are Sirius Red-stained pancreatic sections. Scale bar, $100 \mu \mathrm{m} .{ }^{*} p<0.05,{ }^{* *} p<0.01$ vs vehicle-treated. Values are means $\pm \operatorname{SEM}(n=6-13)$ 
a

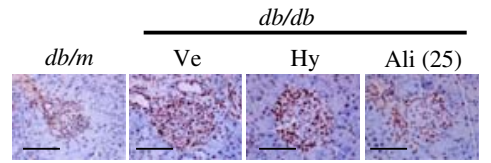

(\%)

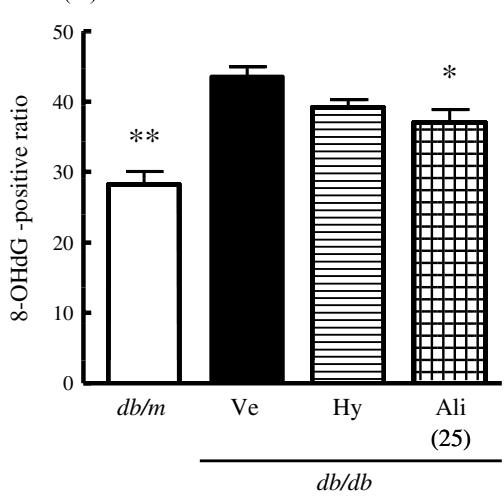

b

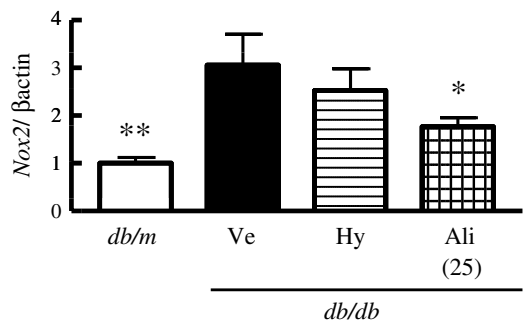

C
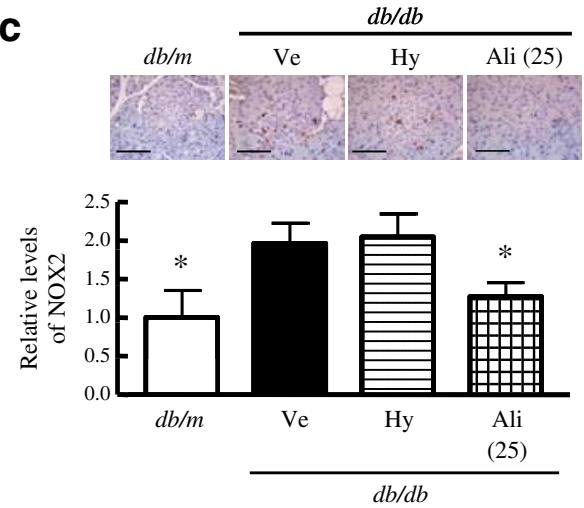

Fig. 11 8-OHdG-positive cells (a), Nox2 mRNA expression (b) and NOX2 protein levels (c) in pancreatic islets of $d b / m$ mice and $d b / d b$ mice. Ve, vehicle-treated; Hy, hydralazine $\left(80 \mathrm{mg} \mathrm{kg}^{-1} \mathrm{day}^{-1}\right)$-treated; Ali (25), aliskiren (25 $\mathrm{mg} \mathrm{kg}^{-1}$ day $^{-1}$ )-treated. a, c Upper panels are representative photomicrographs of pancreatic sections immunostained with anti-8-OHdG antibody and anti-NOX2 antibody, respectively. Scale bar, $100 \mu \mathrm{m} .{ }^{*} p<0.05,{ }^{* *} p<0.01$ vs vehicle-treated. Values are means \pm SEM $(n=6-13)$

the effect of aliskiren on eNOS, since eNOS counteracts superoxide via the production of nitric oxide, and protects against the impairment of vascular endothelial function [22, $39,40]$. We found that aliskiren significantly restored the attenuation of eNOS and phospho-eNOS protein levels in $d b / d b$ mice. Thus, the upregulation of eNOS by aliskiren appears to be responsible for the improvement of vascular endothelial function in type 2 diabetic mice.

In the present study, we also examined the effect of aliskiren on glucose intolerance, insulin resistance and pancreatic injury in type 2 diabetes. We found that aliskiren at the highest dose $\left(25 \mathrm{mg} \mathrm{kg}^{-1}\right.$ day $\left.^{-1}\right)$ exerted partially bene-

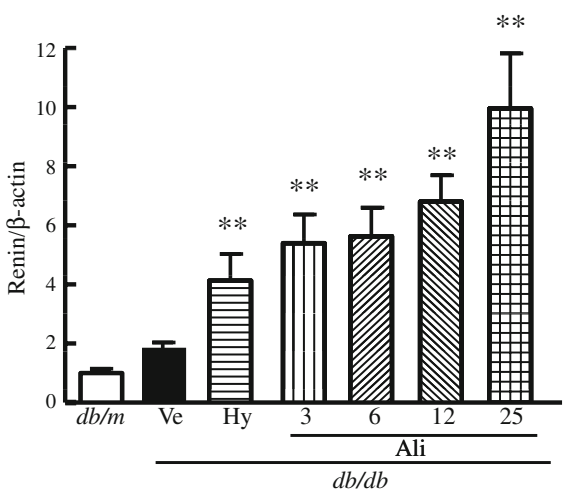

Fig. 12 Renal renin mRNA expression of $d b / m$ mice and $d b / d b$ mice. Ve, vehicle-treated; Hy, hydralazine $\left(80 \mathrm{mg} \mathrm{kg}^{-1}\right.$ day $\left.^{-1}\right)$-treated; Ali (3), Ali (6), Ali (12) and Ali (25), treated with aliskiren at 3, 6, 12 and $25 \mathrm{mg} \mathrm{kg}^{-1}$ day $^{-1}$, respectively. Renin mRNA levels in individual sample were corrected for $\beta$-actin mRNA levels. ${ }^{* *} p<0.01$ vs $d b / m$. Values are means \pm SEM $(n=6-13)$ tection in type 2 diabetes. In this work, we also examined 
ficial effects on glucose tolerance and insulin sensitivity in type 2 diabetic mice, as shown by the IGTT, IITT and HOMA-IR results. However, in contrast to the prevention of cardiovascular injuries by aliskiren at all doses examined, lower doses (3, 6 and $12 \mathrm{mg} \mathrm{kg}^{-1}$ day $^{-1}$ ) of aliskiren failed to improve glucose tolerance in $d b / d b$ mice. These results suggest that the suppression of glucose intolerance by aliskiren may need the use of higher doses than the prevention of cardiovascular injury by aliskiren. To further elucidate the effects of aliskiren on type 2 diabetes, we examined the effect of aliskiren on pancreatic injuries in $d b / d b$ mice, because the impairment of pancreatic function in type 2 diabetic animals is ameliorated by treatment with conventional RAS blockers $[25,41]$. We found that aliskiren significantly attenuated the decrease in pancreatic islet insulin content and beta cell mass and significantly lessened pancreatic islet fibrosis in $d b / d b$ mice, and these beneficial effects of aliskiren were associated with the attenuation of pancreatic oxidative stress, as shown by the reduction of islet 8-OHdG-positive cells and of NADPH oxidase subunit Nox2. Thus, our current work provides the first evidence that aliskiren protects against the damage of pancreatic islets in type 2 diabetic mice through attenuation of oxidative stress. Collectively, aliskiren seems to exert beneficial effects on glucose tolerance. However, further study on the effect of longer periods of aliskiren treatment on glucose tolerance is required to define the significance of renin inhibition in type 2 diabetes.

The present study did not address comparison of aliskiren with conventional RAS blockers in diabetes. Importantly, the effects of an ACE inhibitor and an ARB on glucose tolerance in type 2 diabetic animals, including $d b / d b$ mice, have been controversial, and depend on severity of diabetes, the time of start of drug treatment and the duration of drug treatment [25, 26, 41, 42]. Furthermore, a recent clinical trial [43] showed that the addition of aliskiren to losartan, an ARB, provided additive reduction of urinary albumin excretion in type 2 diabetic patients, suggesting that the combination of aliskiren plus an ARB may be a useful therapeutic strategy for diabetic nephropathy. Further experimental and clinical studies are needed to define the precise efficacy of aliskiren alone or in combination with a conventional RAS blocker in treatment of hypertension with type 2 diabetes.

In conclusion, our present study has provided the first evidence that direct renin inhibition with aliskiren prevents cardiovascular complications and pancreatic injury in obese type 2 diabetic mice, at least partially through the amelioration of oxidative stress. Furthermore, aliskiren seems to exert a partially beneficial effect on glucose tolerance, although future studies on the effect of longer periods of aliskiren treatment are necessary to elucidate it. We propose that aliskiren may be a promising therapeutic agent for type 2 diabetes and its complications.
Acknowledgements This work was supported by Grants-in Aid for Scientific Research from the Japanese Ministry of Education, Culture, Sports, Science and Technology and by a grant from the Novartis Pharmaceutical Corporation.

Duality of interest The authors declare that there is no duality of interest associated with this manuscript.

\section{References}

1. Alderman MH, Cohen H, Madhavan S (1999) Diabetes and cardiovascular events in hypertensive patients. Hypertension 33:1130-1134

2. Genuth S, Alberti KG, Bennett P et al (2003) Follow-up report on the diagnosis of diabetes mellitus. Diabetes Care 26:3160-3167

3. Stamler J, Vaccaro O, Neaton JD, Wentworth D (1993) Diabetes, other risk factors, and 12-yr cardiovascular mortality for men screened in the Multiple Risk Factor Intervention Trial. Diabetes Care 16:434-444

4. Verdecchia P, Reboldi G, Angeli F et al (2004) Adverse prognostic significance of new diabetes in treated hypertensive subjects. Hypertension 43:963-969

5. Yusuf S, Sleight P, Pogue J, Bosch J, Davies R, Dagenais G (2000) Effects of an angiotensin-converting-enzyme inhibitor, ramipril, on cardiovascular events in high-risk patients. The Heart Outcomes Prevention Evaluation Study Investigators. N Engl J Med 342:145-153

6. Abuissa H, Jones PG, Marso SP, O'Keefe JH Jr (2005) Angiotensin-converting enzyme inhibitors or angiotensin receptor blockers for prevention of type 2 diabetes: a meta-analysis of randomized clinical trials. J Am Coll Cardiol 46:821-826

7. Dahlof B, Devereux RB, Kjeldsen SE et al (2002) Cardiovascular morbidity and mortality in the Losartan Intervention for Endpoint Reduction in Hypertension Study (LIFE): a randomised trial against atenolol. Lancet 359:995-1003

8. Julius S, Kjeldsen SE, Weber $M$ et al (2004) Outcomes in hypertensive patients at high cardiovascular risk treated with regimens based on valsartan or amlodipine: the VALUE randomised trial. Lancet 363:2022-2031

9. Prasad A, Quyyumi AA (2004) Renin-angiotensin system and angiotensin receptor blockers in the metabolic syndrome. Circulation 110:1507-1512

10. Brown MJ (2008) Aliskiren. Circulation 118:773-784

11. Jensen C, Herold P, Brunner HR (2008) Aliskiren: the first renin inhibitor for clinical treatment. Nat Rev Drug Discov 7:399-410

12. Gradman AH, Schmieder RE, Lins RL, Nussberger J, Chiang Y, Bedigian MP (2005) Aliskiren, a novel orally effective renin inhibitor, provides dose-dependent antihypertensive efficacy and placebo-like tolerability in hypertensive patients. Circulation 111:1012-1018

13. Oparil S, Yarows SA, Patel S, Fang H, Zhang J, Satlin A (2007) Efficacy and safety of combined use of aliskiren and valsartan in patients with hypertension: a randomised, double-blind trial. Lancet 370:221-229

14. Feldman DL, Jin L, Xuan H et al (2008) Effects of aliskiren on blood pressure, albuminuria, and (pro)renin receptor expression in diabetic TG(mRen-2)27 rats. Hypertension 52:130-136

15. Imanishi T, Tsujioka H, Ikejima $H$ et al (2008) Renin inhibitor aliskiren improves impaired nitric oxide bioavailability and protects against atherosclerotic changes. Hypertension 52:563-572

16. Lu H, Rateri DL, Feldman DL et al (2008) Renin inhibition reduces hypercholesterolemia-induced atherosclerosis in mice. $\mathrm{J}$ Clin Invest 118:984-993 
17. Nussberger J, Aubert JF, Bouzourene K, Pellegrin M, Hayoz D, Mazzolai L (2008) Renin inhibition by aliskiren prevents atherosclerosis progression: comparison with irbesartan, atenolol, and amlodipine. Hypertension 51:1306-1311

18. Pilz B, Shagdarsuren E, Wellner M et al (2005) Aliskiren, a human renin inhibitor, ameliorates cardiac and renal damage in double-transgenic rats. Hypertension 46:569-576

19. Westermann D, Riad A, Lettau O et al (2008) Renin inhibition improves cardiac function and remodeling after myocardial infarction independent of blood pressure. Hypertension 52:10681075

20. Whaley-Connell A, Habibi J, Cooper SA et al (2008) Effect of renin inhibition and AT1R blockade on myocardial remodeling in the transgenic Ren2 rat. Am J Physiol Endocrinol Metab 295: E103-E109

21. Yamamoto E, Dong YF, Kataoka K et al (2008) Olmesartan prevents cardiovascular injury and hepatic steatosis in obesity and diabetes, accompanied by apoptosis signal regulating kinase-1 inhibition. Hypertension 52:573-580

22. Yamamoto E, Yamashita T, Tanaka T et al (2007) Pravastatin enhances beneficial effects of olmesartan on vascular injury of salt-sensitive hypertensive rats, via pleiotropic effects. Arterioscler Thromb Vasc Biol 27:556-563

23. Yamamoto E, Lai ZF, Yamashita T et al (2006) Enhancement of cardiac oxidative stress by tachycardia and its critical role in cardiac hypertrophy and fibrosis. J Hypertens 24:2057-2069

24. Izumiya Y, Kim S, Izumi Y et al (2003) Apoptosis signalregulating kinase 1 plays a pivotal role in angiotensin II-induced cardiac hypertrophy and remodeling. Circ Res 93:874-883

25. Tikellis C, Wookey PJ, Candido R, Andrikopoulos S, Thomas MC, Cooper ME (2004) Improved islet morphology after blockade of the renin-angiotensin system in the ZDF rat. Diabetes 53:989-997

26. Shao J, Iwashita N, Ikeda F et al (2006) Beneficial effects of candesartan, an angiotensin II type 1 receptor blocker, on beta-cell function and morphology in $\mathrm{db} / \mathrm{db}$ mice. Biochem Biophys Res Commun 344:1224-1233

27. Yamamoto E, Kataoka K, Dong YF et al (2009) Aliskiren enhances the protective effects of valsartan against cardiovascular and renal injury in endothelial nitric oxide synthase-deficient mice. Hypertension 54:633-638

28. Habibi J, Whaley-Connell A, Hayden MR et al (2008) Renin inhibition attenuates insulin resistance, oxidative stress, and pancreatic remodeling in the transgenic Ren2 rat. Endocrinology 149:5643-5653
29. Lastra G, Habibi J, Whaley-Connell AT et al (2009) Direct renin inhibition improves systemic insulin resistance and skeletal muscle glucose transport in a transgenic rodent model of tissue renin overexpression. Endocrinology 150:2561-2568

30. Kelly DJ, Zhang Y, Moe G, Naik G, Gilbert RE (2007) Aliskiren, a novel renin inhibitor, is renoprotective in a model of advanced diabetic nephropathy in rats. Diabetologia 50:2398-2404

31. Singh VP, Le B, Khode R, Baker KM, Kumar R (2008) Intracellular angiotensin II production in diabetic rats is correlated with cardiomyocyte apoptosis, oxidative stress, and cardiac fibrosis. Diabetes 57:3297-3306

32. Coleman DL (1982) Diabetes-obesity syndromes in mice. Diabetes 31:1-6

33. Sharma K, McCue P, Dunn SR (2003) Diabetic kidney disease in the $\mathrm{db} / \mathrm{db}$ mouse. Am J Physiol Renal Physiol 284:F1138-F1144

34. Griendling KK, Sorescu D, Ushio-Fukai M (2000) NAD(P)H oxidase: role in cardiovascular biology and disease. Circ Res $86: 494-501$

35. Takimoto E, Kass DA (2007) Role of oxidative stress in cardiac hypertrophy and remodeling. Hypertension 49:241-248

36. Brownlee M (2001) Biochemistry and molecular cell biology of diabetic complications. Nature 414:813-820

37. Evans JL, Goldfine ID, Maddux BA, Grodsky GM (2003) Are oxidative stress-activated signaling pathways mediators of insulin resistance and beta-cell dysfunction? Diabetes 52:1-8

38. Forbes JM, Coughlan MT, Cooper ME (2008) Oxidative stress as a major culprit in kidney disease in diabetes. Diabetes 57:1446-1454

39. Forstermann U, Munzel T (2006) Endothelial nitric oxide synthase in vascular disease: from marvel to menace. Circulation 113:1708-1714

40. Yamamoto E, Kataoka K, Shintaku H et al (2007) Novel mechanism and role of angiotensin II induced vascular endothelial injury in hypertensive diastolic heart failure. Arterioscler Thromb Vasc Biol 27:2569-2575

41. Chu KY, Lau T, Carlsson PO, Leung PS (2006) Angiotensin II type 1 receptor blockade improves beta-cell function and glucose tolerance in a mouse model of type 2 diabetes. Diabetes 55:367-374

42. Nakayama $M$, Inoguchi $T$, Sonta $T$ et al (2005) Increased expression of $\mathrm{NAD}(\mathrm{P}) \mathrm{H}$ oxidase in islets of animal models of type 2 diabetes and its improvement by an AT1 receptor antagonist. Biochem Biophys Res Commun 332:927-933

43. Parving HH, Persson F, Lewis JB, Lewis EJ, Hollenberg NK (2008) Aliskiren combined with losartan in type 2 diabetes and nephropathy. N Engl J Med 358:2433-2446 